\title{
Penerapan Model Pembelajaran Kooperatif Tipe Jigsaw dengan Media Komik Strip untuk Meningkatkan Aktivitas dan Hasil Belajar Kimia Siswa SMK Negeri 4 Gowa
}

\author{
Zaenab \\ SMK Negeri 4 Gowa, Kabupaten Gowa - Provinsi Sulawesi Selatan \\ Corresponding Author. Email: enabesemka@gmail.com
}

\begin{abstract}
This study aims to describe the application of the jigsaw cooperative model with comic strip media to increase students' activity and chemistry learning outcomes. This research method used classroom action research, including four stages of implementation, namely: planning, action, observation, and reflection. The subjects in this study were students of class X TKJ 3 SMK Negeri 4 Gowa with a total of 35 students. The research instrument used observation, tests, and documentation. The data analysis technique used descriptive qualitative and quantitative. The results of this study indicate that the mean score of students obtained after the first cycle was 5.9 which was at moderate intervals. Descriptively the results of this study also revealed that the results of learning chemistry class X TKJ3 SMK Negeri 4 Gowa who took the jigsaw cooperative learning type using comic strip media in cycle II was 7.3 which was at high intervals. In cycle I, there were no students who got very high scores and there were still students who had scores in the low category, namely around 28.5 or about 10 students. In Cycle II, students who scored in the very high category were around 14.3 and no students who scored in the low or very low category were found. In general, it can be said that there is an increase in student learning outcomes through the application of the jigsaw cooperative learning model at SMK Negeri 4 Gowa.
\end{abstract}

\begin{abstract}
Abstrak: Penelitian ini bertujuan untuk mendeskripsikan penerapan model kooperatif tipe jigsaw dengan media komik strip untuk meningkatkan aktivitas dan hasil belajar kimia siswa. Metode penelitian ii menggunakan penelitian tindakan kelas, meliputi empat tahap pelaksanaan yaitu: perencanaan, tindakan, observasi, dan refleksi. Subjek dalam penelitian ini adalah siswa kelas X TKJ 3 SMK Negeri 4 Gowa dengan jumlah 35 orang siswa. Instrumen penelitian ini menggunakan observasi, tes, dan dokumentasi. Teknik analisis data menggunakan deskriptif kualitatif dan kuantitatif. Hasil penelitian ini menunjukkan bahwa nilai rata-rata siswa yang diperoleh setelah siklus I adalah 5,9 yang berada pada interval sedang. Secara deskriptif hasil penelitian ini juga mengungkapkan bahwa hasil belajar kimia siswa kelas X TKJ $\mathrm{T}_{3} \mathrm{SMK}_{\text {Negeri }} 4$ Gowa yang mengikuti pembelajaran kooperatif tipe jigsaw dengan menggunakan media komik strip pada siklus II adalah 7,3 yang berada pada interval tinggi. Pada siklus I tidak didapatkan siswa yang memperoleh nilai sangat tinggi dan masih didapatkan siswa yang memiliki nilai pada ketegori rendah yaitu sekitar 28,5 atau sekitar 10 orang siswa. Siklus II mendapatkan siswa yang memperoleh nilai pada ketegori sangat tinggi yaitu sekitar 14,3 dan sudah tidak ditemukan siswa yang memiliki nilai pada kategori rendah atau sangat rendah. Secara umum dapat dikatakan bahwa terjadi peningkatan hasil belajar siswa yang belajar melalui penerapan model pembelajaran kooperatif tipe jigsaw di SMK Negeri 4 Gowa.
\end{abstract}

How to Cite Zaenab, Z. (2021). Penerapan Model Pembelajaran Kooperatif Tipe Jigsaw dengan Media Komik Strip untuk Meningkatkan Aktivitas dan Hasil Belajar Kimia Siswa SMK Negeri 4 Gowa. Jurnal Teknologi Pendidikan : Jurnal Penelitian dan Pengembangan Pembelajaran, 6(1). doi:https://doi.org/10.33394/jtp.v6i1.3602
Article History

Received: 29-02-2021

Revised: 17-03-2021

Published: 14-04-2021

\section{Key Words:}

Cooperative, Jigsaw, Media, Comic Strip, Activities, Learning Outcomes.

\section{Sejarah Artikel}

Diterima: 29-02-2021

Direvisi: 17-03-2021

Diterbitkan: 14-04-2021

\section{Kata Kunci:}

Kooperatif, Jigsaw, Media, Komik Strip, Aktivitas, Hasil Belajar. 


\section{Pendahuluan}

Salah satu model pembelajaran yang didasarkan konstruktivisme yang dikembangkan saat ini adalah model pembelajaran kooperatif yang mengarahkan siswa untuk bekerja sama dalam kelompok kecil dan saling membantu dalam belajar. Satu aspek penting pembelajaran kooperatif ialah bahwa di samping pembelajaran kooperatif membantu mengembangkan tingkah laku kooperatif dan hubungan yang lebih baik di antara siswa, pembelajaran kooperatif secara bersamaan membantu siswa dalam pembelajaran akademis. Oleh karena itu dalam proses belajar mengajar, guru dituntut dapat memilih dan menggunakan metode yang cocok agar pencapaian materi pelajaran tersebut lebih efektif dan efisien seperti halnya menggunakan metode mengajar yang banyak melibatkan peran serta siswa dalam belajar seperti metode pembelajaran kooperatif tipe jigsaw, sehingga hasil belajar siswa dapat meningkat (Faiq, 2009; Nur dkk., 2000; Karlina, 2004).

Pembelajaran kooperatif tipe jigsaw merupakan salah satu metode pembelajaran yang mengelompokkan siswa dalam kelompok kecil (4-5 siswa) perkelompok, dimana pada kelompok ini setiap siswa akan bekerjasama dan bertanggungjawab atas keberhasilan semua anggota kelompoknya, pembelajaran dengan metode jigsaw akan membuat suasana pembelajaran menjadi aktif, kreatif dan menyenangkan (Heryekti P., 2021; Asni, 2017: Pratini, 2015); Fajuri, 2019; Aspari, 2020; Nashirotun, 2020). Selanjutnya Isjoni (2011) menyatakan jigsaw merupakan salah satu tipe pembelajaran kooperatif yang mendorong siswa aktif dan membantu dalam menguasai materi pelajaran untuk mencapai prestasi yang maksimal.

Selain model pembelajaran, penggunaan media dalam mengajar sangat penting dalam meningkatkan aktivitas dan hasil belajar siswa. Dalam proses pembelajaran dengan menggunakan media pembelajaran berbasis teknologi informasi dan komunikasi akan memberikan suatu pandangan baru dan luas bagi guru untuk lebih berkonsentrasi menjadi fasilitator, sehingga pembelajaran menjadi lebih fokus pada partisipasi siswa. Ini sejalan dengan Peraturan Pemerintah Republik Indonesia Nomor 19 Tahun 2005 tentang Standar Nasional Pendidikan pasal 19 ayat 1 dinyatakan bahwa : Proses pembelajaran pada satuan pendidikan diselenggarakan secara interaktif, inspiratif, menyenangkan, menantang, memotivasi peserta didik untuk berpartisipasi aktif serta memberikan ruang yang cukup bagi prakarsa,kreativitas dan kemandirian sesuai dengan bakat,minat dan perkembangan fisik serta psikologis peserta didik.

Sejalan dengan hal itu, maka peran guru sebagai fasilitator pada pencapaian standar proses pendidikan, khususnya yang berkaitan dengan pemanfaatan media, guru diharapkan memahami berbagai jenis media pembelajaran dan fungsinya serta terampil merancang media yang cocok, berkomunikasi dan interaktif dengan siswa sehingga pesan tersampaikan dan menumbuhkan motivasi siswa untuk berpartisipasi dalam pembelajaran. Bila penggunaan media pembelajaran yang interaktif maka akan berdampak positif akan menarik perhatian siswa, meningkatkan kualitas pembelajaran sehingga aktivitas siswa menjadi meningkat.

Dalam pembelajaran kimia di sekolah menengah atas, disamping menganalisa, menghitung dan menemukan berbagai fakta dalam kehidupan juga perlu kegiatan membaca teori-teori sehubungan dengan pembelajaran dengan materi struktur atom. Oleh karena itu, suatu pembelajaran perlu dirancang supaya siswa tertarik untuk belajar membaca. Pemahaman dalam membaca merupakan suatu keterampilan yang menwajibkan siswa untuk memahami isi bacaan serta mencari hubungan sebab akibat dalam suatu bacaan. Bacaan yang dapat digunakan sebagai media pembelajaran adalah media komik, yang merupakan suatu bacaan favorit siswa. Media komik memiliki ilustrasi gambar dari cerita yang disajikan. 
Media komik memiliki gambar yang berwarna sehingga menjadi daya tarik tersendiri bagi siswa dalam membacanya. Media komik merupakan salah satu alternatif media dalam pembelajaran, tidak membutuhkan banyak alat dan sarana khusus untuk penggunaannya dan menggunakan visualnya saja. Mudah dan praktis dalam penggunaannya di depan kelas penggunaan media komik dalam pembelajaran dapat membantu siswa untuk berpartisipasi dalam pembelajaran kimia. Media komik dirancang sesuai kebutuhan siswa dan disesuaikan dengan materi yang akan disampaikan serta dapat memotivasi siswa untuk lebih semangat dalam belajar karena media komik yang digunakan sebagai media pembelajaran dapat berfungsi sebagai penyampaian pesan pembelajaran yang disajikan dengan semenarik mungkin hingga siswa lebih tertarik untuk belajar.

Berdasarkan hasil observasi khususnya pada siswa kelas $X \mathrm{TKJ}_{3}$ di SMK Negeri 4 Gowa, ditemukan fakta rendahnya aktivitas dan hasil belajar siswa dalam proses pembelajaran, sehingga dipandang penting untuk melakukan penelitian dengan tujuan untuk meningkatkan aktivitas dan hasil belajar kimia siswa melalui penerapan model kooperatif tipe jigsaw dengan media komik strip.

\section{Metode Penelitian}

Metode penelitian yang digunakan adalah penelitian tindakan kelas (Classroom Action Research) dengan subjek penelitian adalah siswa kelas X TKJ3 di SMK Negeri 4 Gowa pada semester ganjil tahun pelajaran 2019/2020 dengan jumlah 35 siswa. Penelitian ini meliputi empat tahap pelaksanaan yaitu: perencanaan, tindakan, observasi, dan refleksi dengan model sebagai berikut :

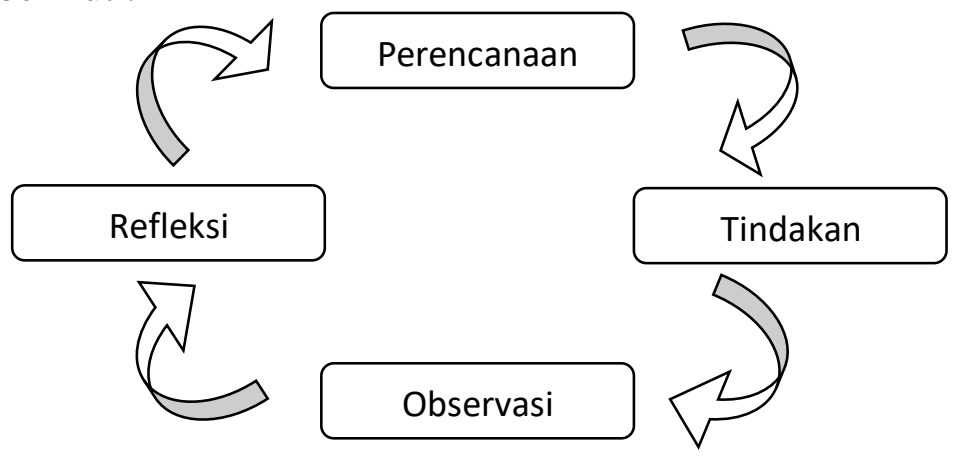

Gambar 1. Tahap Pelaksanaan Penelitian

Pada siklus I terdiri dari empat kali pertemuan dan pada siklus II terdiri dari lima kali pertemuan. Setiap pertemuan menggunakan alokasi waktu 2 x 40 menit. Instrumen penelitian ini menggunakan observasi, tes, dan dokumentasi. Analisis kualitatif dilakukan dengan menggunakan teknik presentase aktivitas belajar siswa, sedangkan untuk analisis kuantitatif penyajiaan datanya dilakukan dalam bentuk tabel distribusi frekuensi dimana dapat dikelompokkan ke dalam beberapa kelompok. Data yang terkumpul dianalisis secara kuantitatif dan kualitatif. Untuk keperluan analisis statistik deskriptif, maka digunakan tabel distribusi skor, rata-rata dan standar deviasi.

\section{Hasil Penelitian dan Pembahasan}

Pada pelaksanaan tindakan ini dilakukan dua siklus kegiatan, yaitu siklus I dan siklus II. Pada akhir siklus I diberikan evaluasi sebagai tidak lanjut untuk mengetahui tingkat keberhasilan siswa dalam pelaksanaan tindakan, serta untuk merencanakan tindakan selanjutnya yaitu siklus II. Pada akhir siklus II juga diberikan evaluasi dan refleksi yang 
berkaitan dengan peningkatan hasil belajar fisika siswa melalui penerapan pembelajaran kooperatif tipe Jigsaw.

Hasil analisis deskriptif pada skor hasil belajar kimia siswa terhadap materi yang diajarkan pada siklus I dapat dilihat pada tabel berikut ini.

Tabel 1. Statistik Skor Tes Hasil belajar Siswa terhadap Materi dengan Menerapkan Pembelajaran Kooperatif tipe Jigsaw yang Diajarkan pada Siklus I

\begin{tabular}{|l|c|}
\hline \multicolumn{1}{|c|}{ Variabel } & Nilai statistik \\
\hline Skor ideal & 10.0 \\
\hline Skor tertinggi & 7.7 \\
\hline Skor terendah & 2.0 \\
\hline Rentang skor & 5.7 \\
\hline Rata-rata skor & 5.9 \\
\hline Simpangan baku & 1.4 \\
\hline
\end{tabular}

Skor rata-rata hasil belajar siswa terhadap materi setelah diberikan pembelajaran kooperatif tipe Jigsaw yang didasarkan pada siklus I adalah sebesar 5,9 dan skor ideal yang mungkin dicapai 10,0 dan standar deviasi 1,4. Sedangkan secara individual. skor yang dicapai responden tersebar dan skor terendah 2,0 dan skor tertinggi yang mungkin 10,0 dicapai sampai dengan skor tertinggi 7,7 dan skor tertinggi yang mungkin 10,0 dicapai dengan rentang 5,7 ini menunjukkan bahwa hasil belajar siswa cukup bervariasi dan hasil belajar yang rendah $(2,0 \%)$ sampai dengan hasil tes yang sangat tinggi $(7,7 \%)$.

Setelah skor responden dikelompokkan dalam lima kelompok (kelas) maka diperoleh distribusi frekuensi nilai seperti disajikan pada tabel 2.

Tabel 2. Distribusi Frekuensi dan Persentase Skor Hasil belajar Siswa terhadap Materi dengan Pendekatan Kooperatif Tipe Jigsaw pada Siklus I

\begin{tabular}{|l|l|c|c|}
\hline \multicolumn{1}{|c|}{ Skor } & \multicolumn{1}{c|}{ Kategori } & Frekuensi & Persentase (\%) \\
\hline $0-3.4$ & Sangat rendah & 2 & 5,7 \\
\hline $3.5-5.4$ & Rendah & 10 & 28,5 \\
\hline $5.5-6.4$ & Sedang & 8 & 22,9 \\
\hline $6.5-8.4$ & Tinggi & 15 & 42,9 \\
\hline $8.5-10.0$ & Sangat tinggi & - & - \\
\hline \multicolumn{2}{r|}{ Jumlah } & 35.0 & 10.0 \\
\hline
\end{tabular}

Dari tabel 2 diperlihatkan bahwa setelah siswa diberikan pembelajaran kooperatif tipe Jigsaw pada siklus I hasil belajar siswa cukup bervariasi. Di samping itu, sesuai dengan ratarata skor hasil belajar siswa terhadap sistem gerak dan dinamika partikel 5,9 dan skor ideal yang mungkin dicapai 10,0 dan standar deviasi 14. Jika dikonversi ke dalam tabel, ternyata berada dalam kategori tinggi, hal ini berarti bahwa hasil belajar siswa setelah pemberian pembelajaran kooperarif tipe Jigsaw berada dalam kategori tinggi.

Dari tabel 3 dan tabel 4 dapat dilihat bahwa skor siswa cenderung berada pada 5.9 dan skor ideal yang mungkin dicapai 10,0 dan standar deviasi 1,4 dan berada tingkat tinggi, namun diperlihatkan oleh persentase banyaknya siswa yang berada pada tingkat yang hasil belajarnya tinggi, namun diperlihatkan oleh persentase banyaknya siswa yang berada pada tingkat hasil belajar yang tinggi sebesar $42,9 \%$ atau 15 orang dari 35 orang siswa, tetapi masih banyak siswa yang berada pada tingkat yang hasil belajarnya rendah sebanyak 10 orang siswa dan 35 orang siswa atau sekitar $28,5 \%$ dan sedang sebanyak 8 orang siswa dan 35 orang siswa atau sekitar $22,9 \%$ serta sangat rendah sekali banyak 2 orang siswa atau 
sekitar 5,7\%. Apabila hasil tes hasil belajar siswa pada siklus I dianalisis maka persentase ketuntasan belajar siswa pada siklus I dapat dilihat pada tabel 3.

Tabel 3. Distribusi Frekuensi dan Persentase Skor Hasil Belajar Siswa terhadap Materi dengan Pendekatan Kooperatif Tipe Jigsaw pada Siklus I

\begin{tabular}{|c|c|c|c|}
\hline $\begin{array}{c}\text { Persentase } \\
\text { skor }\end{array}$ & Kategori & Frekuensi & Persentase (\%) \\
\hline $0-68.9$ & Tidak tuntas & 20 & 57,1 \\
\hline $70-100$ & Tuntas & 15 & 42,9 \\
\hline \multicolumn{2}{|c|}{ Jumlah } & 35.0 & 100.0 \\
\hline
\end{tabular}

Dari tabel 3 menunjukkan persentase ketuntasan belajar siswa sebesar 42,9\% yaitu 15 dari 35 siswa termasuk dalam kategori tuntas dan 57,1\% atau 20 dari 35 siswa termasuk dalam kategori tidak tuntas, berarti terdapat 20 siswa yang perlu perbaikan karena mereka belum mencapai kriteria ketuntasan individual. Dari tabel ditas memperlihatkan, walaupun 42,9\% siswa menunjukkan tingkat hasil tes tinggi namun ternyata pada tabel 5 masih banyak siswa yang hasil belajarnya belum tuntas yaitu sekitar $57,1 \%$ atau 20 siswa dari 35 siswa yang masih perlu perbaikan.

Hasil analisis deskriptif menunjukkan bahwa rata-rata skor yang dicapai oleh siswa terhadap materi yang diajarkan dengan penerapan pembelajaran kooperatif tipe Jigsaw yang diajarkan pada siklus II dapat dilihat pada Tabel 4.

Tabel 4. Statistik Skor Hasil belajar Siswa terhadap Materi dengan Penerapan Pembelajaran Kooperatif tipe Jigsaw pada Siklus II

\begin{tabular}{|l|c|}
\hline \multicolumn{1}{|c|}{ Variabel } & Nilai statistik \\
\hline Skor ideal & 10.0 \\
\hline Skor tertinggi & 9.0 \\
\hline Skor terendah & 5.0 \\
\hline Rentang skor & 4.0 \\
\hline Rata-rata skor & 7.3 \\
\hline Simpangan baku & 1.1 \\
\hline
\end{tabular}

Rata-rata skor hasil tes siswa setelah diberikan pembelajaran kooperatif tipe Jigsaw yang diajarkan pada siklus $\mathrm{H}$ adalah sebesar 7,3 dan skor ideal yang mungkin dicapai 10,0 dan standar deviasi 1,1. Sedangkan secara individual skor yang dicapai responden tersebar dan skor terendah 5,0 dan skor terendah yang mungkin dicapai 10,0 sampai dengan skor tertinggi 9,0 dan skor tertinggi yang mungkin dicapai 10,0. ini menunjukkan bahwa hasil belajar kimia siswa setelah akhir siklus II pada materi struktur atom cukup bervariasi dan hasil belajar kimia siswa yang rendah $(5,0 \%)$ sampai dengan hasil belajar kimia yang cukup tinggi $(9,0 \%)$. Setelah skor responden dikelompokkan dalam lima kelompok (kelas) maka diperoleh distribusi frekuensi nilai seperti disajikan pada tabel 5.

Tabel 5. Distribusi Frekuensi dan Persentase Skor Hasil Belajar Siswa terhadap Materi dengan Pendekatan Kooperatif Tipe Jigsaw pada Siklus II

\begin{tabular}{|l|l|c|c|}
\hline \multicolumn{1}{|c|}{ Skor } & \multicolumn{1}{c|}{ Kategori } & Frekuensi & Persentase (\%) \\
\hline $0-3.4$ & Sangat rendah & - & - \\
\hline $3.5-5.4$ & Rendah & 2 & 5,7 \\
\hline $5.5-6.4$ & Sedang & 8 & 22,9 \\
\hline $6.5-8.4$ & Tinggi & 20 & 57,1 \\
\hline $8.5-10.0$ & Sangat tinggi & 5 & 14,3 \\
\hline \multicolumn{2}{|l|}{ Jumlah } & 35.0 & 10.0 \\
\hline
\end{tabular}


Dari tabel 5 diperlihatkan bahwa setelah siswa diberikan pembelajaran kooperatif tipe Jigsaw pada siklus II hasil belajar siswa bervariasi. Di samping itu, sesuai dengan rata-rata skor hasil belajar siswa sebesar 7,3 dan skor ideal yang mungkin dicapai 10,0 dan standar deviasi 1,1. Jika dikonversi ke dalam tabel, ternyata berada dalam kategori tinggi. Hal ini berarti bahwa hasil belajar siswa setelah pemberian pembelajaran kooperatif tipe Jigsaw pada siklus II berada dalam kategori tinggi.

Dalam Tabel diatas dapat dilihat bahwa skor siswa pada siklus II cenderung berada pada 73 dan skor ideal 10,0 dan standar deviasi 1,1 hal ini memperlihatkan hasil tes siswa berada pada tingkat yang tinggi, namun diperlihatkan oleh persentase banyaknya siswa yang hasil belajarnya sangat tinggi yaitu sebesar $14,3 \%$ atau 5 orang dari 35 orang siswa, hal yang sangat menggembirakan ternyata siswa yang hasil belajarnya tinggi dan terjadi penurunan drastis untuk siswa yang mempunyai hasil belajar yang rendah ini memperlihatkan adanya peningkatan pada siklus I ke siklus II. Apabila hasil tes hasil belajar siswa pada siklus II dianalisis maka persentase ketuntasan belajar siswa pada siklus II dapat dilihat pada tabel 6 .

Tabel 6. Distribusi Frekuensi dan Persentase Skor Hasil Belajar Siswa terhadap Materi dengan Pendekatan Kooperatif Tipe Jigsaw pada Siklus II

\begin{tabular}{|c|c|c|c|}
\hline $\begin{array}{c}\text { Persentase } \\
\text { skor }\end{array}$ & Kategori & Frekuensi & Persentase (\%) \\
\hline $0-68.9$ & Tidak tuntas & 10 & 28,6 \\
\hline $70-100$ & Tuntas & 25 & 71,4 \\
\hline \multicolumn{2}{|c|}{ Jumlah } & 35.0 & 100.0 \\
\hline
\end{tabular}

Dari tabel 6 menunjukkan pada siklus II persentase ketuntasan belajar siswa yaitu 25 orang siswa $71,4 \%$ dari 35 siswa termasuk dalam kategori tuntas dan 10 orang siswa atau sekitar 28,6\% dari 35 siswa termasuk dalam kategori tidak tuntas. ini menunjukkan bahwa hasil belajar siswa meningkat. Untuk melihat hasil tes hasil belajar siswa pada tiap siklus, dapat dilihat pada Tabel 7 berikut ini.

Tabel 7. Hasil Tes Hasil Belajar Siswa pada Setiap Siklus

\begin{tabular}{|l|c|c|c|c|c|c|c|}
\hline \multirow{2}{*}{ No } & \multirow{2}{*}{ Siklus } & \multicolumn{2}{|c|}{ Skor perolehan siswa $(\mathbf{n = 3 5})$} & \multicolumn{2}{c|}{ Ketuntasan } & \multirow{2}{*}{ Daya } \\
\cline { 3 - 7 } & Tertinggi & Terendah & $\begin{array}{c}\text { Rata- } \\
\text { rata }\end{array}$ & Tuntas & $\begin{array}{c}\text { Tidak } \\
\text { tuntas }\end{array}$ & serap \\
\hline 1. & I & 7.7 & 2.0 & 5.9 & 15 & 20 & 36.6 \\
\hline 2. & II & 9.0 & 5.0 & 7.3 & 25 & 10 & 71,4 \\
\hline
\end{tabular}

Dari Tabel 7 terlihat adanya peningkatan tingkatan hasil belajar siswa pada siklus I ke siklus II, begitupun daya serap yang dimiliki siswa.

Berdasarkan hasil penelitian yang telah dianalisis, dapat dilihat bahwa hasil tes siswa setelah dilakukan pembelajaran kooperatif tipe Jigsaw mengalami peningkatan. Hal ini dapat kita lihat dan meningkatnya skor rata-rata, skor tertinggi dan median dan hasil belajar siswa. Dan terjadi penurunan standar deviasi dan hasil tes belajar siswa, yang berarti semakin rendah penyimpangan hasil belajar siswa. Selain itu juga, dapat dilihat semakin bertambahnya siswa memperoleh skor tinggi dan skor sangat tinggi. Skor rata-rata hasil belajar siswa jika dikonversi ke dalam kategorisasi skala lima berada dalam kategori tinggi. Hal ini menunjukkan bahwa kualitas hasil belajar kimia siswa semakin meningkat.

\section{Penekanan Media Komik Strip Siswa}

Berdasarkan hasil penilaian kimia siswa, terlihat terjadi perubahan perilaku belajar yang sangat besar diri siswa. ini dapat dilihat dengan meningkatnya kerja sama antara siswa yang berpengaruh pada meningkatnya nilai (keterampilan bertanya, menjawab, berpendapat 
dan praktikum). Tugas-tugas belajar yang diberikan pada awal pertemuan pembelajaran pada umumnya masih sulit dikerjakan, dalam hal ini disebabkan karena:

a) Masih kurangnya kerja sama antar siswa.

b) Siswa belum berani untuk mengajukan pertanyaan kepada guru, walaupun masih ada materi yang belum dimengerti.

c) Siswa masih terlihat tegang dalam proses belajar mengajar di kelas.

Pada pemberian tindakan pembelajaran selanjutnya siswa sudah mulai beradaptasi dengan pembelajaran kooperatif tipe Jigsaw. Siswa sudah bisa bekerja sama dengan temantemannya, siswa sudah mulai bertanya dan menjawab pertanyaan guru, suasana belajar lebih aktif. ini membuktikan bahwa dengan penggunaan pembelajaran kooperatif tipe Jigsaw hasil belajar siswa dapat ditingkatkan. Kondisi yang lain, dengan pembelajaran kooperatif tipe Jigsaw ini siswa lebih termotivasi dan lebih aktif dalam belajar, siswa lebih berani bertanya, dan menawarkan ide atau menjawab pertanyaan serta lebih aktif membantu temannya dalam belajar dan bekerja secara berkelompok. Kondisi seperti ini menggambarkan peningkatan hasil belajar kimia siswa khususnya.

\section{Perubahan Sikap Siswa}

Di samping terjadinya peningkatan hasil belajar siswa selama penelitian pada siklus I dan siklus II tercatat sejumlah perubahan yang terjadi pada sikap siswa. Perubahan tersebut merupakan data kualitatif yang diperoleh dan lembar observasi pada setiap pertemuan yang dicatat pada tiap siklus dan catatan guru untuk mengetahui perubahan sikap siswa selama proses belajar mengajar berlangsung di kelas. Adapun perubahan-perubahan yang dimaksud adalah sebagai berikut:

a) Meningkatnya frekuensi kehadiran siswa, dan siklus I sebesar 95,6\% siswa selama 4 (empat) kali pertemuan menjadi 97,7\% pada siklus II sebanyak 4 (empat) kali pertemuan. ini membuktikan bahwa siswa memiliki kemampuan dan kemauan untuk mengikuti pelajaran dan ketidakhadiran siswa itu kebanyakan dikarenakan siswa sakit atau izin dengan keperluan lain yang juga penting.

b) Perhatian siswa pada proses belajar mengajar di kelas meningkat dan siklus I ke siklus II dilihat dan semakin banyaknya siswa yang diperhatikan suatu materi. Dan siklus I sebesar 91,2\% siswa meningkatkan menjadi 94,6\% siswa pada siklus

c) Siswa yang melakukan kegiatan sesuai dengan bimbingan guru dalam rangka pengembangan konsep seperti menemukan jawaban soal dalam bentuk cerita dimana siswa harus menganalisis soal tersebut sehingga dapat menentukan unsur-unsur yang diketahui dan unsur yang dinyatakan. Mengalami peningkatan dan siklus I hanya sekitar 8 $8,8 \%$ siswa meningkat menjadi $93,2 \%$ pada siklus II.

d) Siswa yang menjawab pertanyaan yang diajukan pada saat pengembangan konsep meningkat dan $31,7 \%$ siswa pada siklus I ke $34,1 \%$ pada siklus II. ini menunjukkan bahwa ada keberanian dan semangat siswa dalam menjawab pertanyaan yang diberikan.

e) Siswa yang mengemukakan pendapatnya mengenai materi yang dibahas meningkat ini membuktikan bahwa keberanian dan kreatif siswa meningkat dan 19,0\% siswa pada siklus I meningkat $22,4 \%$ pada siklus II.

f) Siswa yang bertanya tentang materi pelajaran yang belum dimengerti mengalami penurunan, dan siklus I sebesar 17,6\% siswa menurun menjadi $11,7 \%$ siswa pada siklus II, ini menunjukkan bahwa siswa makin paham akan materi pelajaran.

g) Keaktifan siswa dalam belajar dan siklus I ke siklus II memperlihatkan peningkatan, ditandai dengan semakin banyaknya siswa yang aktif dalam mengerjakan latihan soal 
untuk lebih mempermantap pengetahuan mereka. Hal ini terlihat adanya peningkatan dan siklus I sebesar 92,7\% siswa menjadi 95,6\% siswa pada siklus II.

h) Siswa yang aktif mengerjakan pekerjaan rumah yang diberikan pada setiap kali pertemuan mengalami peningkatan dan siklus I sebesar 94,2\% siswa menjadi 95,6\% siswa pada siklus II.

i) Timbulnya kesadaran pada diri siswa yang ditandai dengan berkurangnya siswa yang melakukan kegiatan lain pada saat pembahasan materi. dari siklus I sebesar 11,2\% siswa menjadi 3,4\% siswa pada siklus II.

\section{Refleksi Pelaksanaan Tindakan dalam Proses Belajar Mengajar}

Refleksi setiap siklus tidak dijelaskan setiap pertemuan hanya dijelaskan setiap minggu karena tidak ada perubahan yang signifikan. Adapun refleksi setiap siklus adalah sebagai berikut:

\section{Refleksi Siklus I}

1) Minggu I dan II (2 kali pertemuan) penelitian

Kegiatan proses belajar mengajar berjalan cukup baik karena kegiatan pembelajaran yang diterima siswa mudah dimengerti dengan pembentukan kelompok sehingga memudahkan siswa untuk belajar bersama. Perhatian siswa terhadap proses belajar mengajar dengan menggunakan metode pembelajaran kooperatif tipe Jigsaw meningkat. Hal ini dilihat dengan peningkatan siswa memperhatikan penekanan suatu materi, siswa-siswa yang melakukan kegiatan pada saat pembahasan materi tersebut atau pada proses belajar mengajar berlangsung berbeda dan pertemuan pertama sampai pada pertemuan kedua hampir tidak terjadi perubahan, tetapi pada pertemuan berikutnya hingga pertemuan terakhir siswa yang melakukan kegiatan lain (jalan-jalan, ngobrol/cerita dengan temannya) sudah berkurang.

Pada umumnya siswa yang menyenangi kimia dengan metode pembelajaran kooperatif tipe Jigsaw yang diberikan karena metode ini kebanyakan mengerjakan soal-soal latihan dengan cara kerja sama antara anggota kelompok sehingga membuat siswa lebih mudah mengerti dan pelajaran yang dipelajari selalu tersimpan dalam ingatan. Kehadiran siswa dalam mengikuti kegiatan belajar mengajar, khususnya pelajaran kimia sangat meningkat. Jika pada pertemuan-pertemuan pertama jumlah siswa yang tidak hadir ada 3 orang begitu pun untuk pertemuan berikutnya jumlah siswa yang tidak hadir bervariasi tetapi pada pertemuan terakhir siswa hadir semua. Kendala yang dirasakan penulis pada saat penelitian, karena banyaknya siswa yang aktif bertanya karena belum mengerti dan membutuhkan bimbingan sehingga penulis kadang memerlukan waktu yang cukup lama pada saat pembelajaran berlangsung. Akibat dan hal tersebut proses belajar mengajar relatif cukup lama sehingga tidak mengalami peningkatan.

2. Minggu III, dan IV ( 2 kali pertemuan) penelitian

Pada minggu III kegiatan proses belajar mengajar berjalan lancar karena kegiatan pembelajaran yang diterima siswa mudah dimengerti dan terlihat juga kerja sama antara anggota kelompok yang semakin baik. Siswa sudah mulai rajin mengikuti pelajaran, dapat dilihat dengan meningkatnya siswa yang hadir. Kemudian sikap siswa menjadi lebih baik terhadap belajar kimia, hal ini dapat dilihat dan kerajinan siswa dalam mengerjakan tugas latihan, pekerjaan rumah yang diberikan oleh guru.

Siswa yang melakukan kegiatan yang tidak sesuai dengan perintah guru seperti ribut, jalan-jalan dalam kelas, dan lain-lain sudah mulai berkurang dan siswa kesadaran untuk belajar mulai tumbuh.Selama minggu IV ini berlangsung siswa tetap bersemangat dalam mengerjakan tugas yang diberikan oleh guru baik itu tugas-tugas latihan di kelas maupun pekerjaan rumah yang dapat didiskusikan dengan teman ataupun saudara sehingga hasilnya 
menjadi lebih baik. Juga siswa yang bertanya tentang materi yang belum dimengerti sudah bertambah ini berarti bahwa kemauan siswa untuk belajar sudah ada.

Berdasarkan hasil pemantauan dan evaluasi selama empat kali pertemuan, skenario tindakan berubah sesuai dengan kasus dan tujuan yang ingin dicapai melalui penelitian. Selama berlangsung kegiatan tersebut, hingga akhir penelitian siklus I dapat dikemukakan bahwa kegiatan penelitian telah menemukan bentuk tersendiri sesuai dengan yang dikehendaki, meskipun disadari bahwa apa yang ingin dicapai pada siklus I ini masih jauh dan yang diinginkan. Meskipun demikian, memasuki minggu kelima yaitu pada pertemuan kelima terlihat kegiatan penelitian cenderung menunjukkan hasil seperti yang diinginkan berdasarkan pemantauan evaluasi yang dilakukan oleh guru. Pada pertemuan tersebut jumlah siswa yang memahami materi yang diberikan berdasarkan pembelajaran kooperatif tipe Jigsaw mengalami peningkatan dan tiap pertemuan. Dilihat dan hasil pekerjaan siswa saat diberikan soal-soal baik pada saat pembelajaran maupun latihan yang dijadikan pekerjaan rumah.

Meskipun demikian proses belajar mengajar masih terlihat siswa yang bersikap pasif yang hanya diam bahkan melakukan kegiatan lain. Siswa yang demikian ini umumnya kurang memahami materi yang diberikan sehingga cenderung menghindar jika guru mendekatinya untuk dibimbing bahkan dengan sengaja bersikap seolah-olah siswa sudah memahami materi, terlebih jika siswa tersebut diberi kesempatan ke depan kelas untuk mengerjakan soal-soal.

\section{Refleksi Siklus II}

Siklus II ini terdiri dari 4 kali pertemuan. Pada siklus II ini terlihat banyaknya siswa yang memperhatikan materi mengalami peningkatan, sedangkan siswa yang melakukan kegiatan lain pada proses belajar mengajar yang sedang berlangsung sudah berkurang. Hal ini dapat dilihat dalam lampiran di mana siswa lebih aktif dalam proses belajar mengajar terlebih pada saat siswa diberikan kesempatan untuk menjawab dan mengemukakan pendapatnya.

Pada siklus II siswa tidak lagi banyak bertanya atau meminta bimbingan guru. Hal lain yang terjadi pada siklus II adalah peningkatan rata-rata nilai hasil belajar siswa. Untuk itu kemampuan siswa menerima materi pelajaran kimia lebih baik lagi, demikian pula keaktifan siswa dalam menyelesaikan soal-soal latihan atau materi yang diterima semakin meningkat pula. Jika sebelumnya suatu materi kurang dimengerti dan disenangi siswa sudah langsung menangkap atau dengan cepat memahami materi dengan sekali atau dua kali penjelasan.

\section{Analisis Refleksi Siswa}

Analisis terhadap refleksi yang dibuat siswa sebagai berikut.

1) Pendapat siswa tentang pelajaran

Sebagian besar siswa mengatakan bahwa pelajaran kimia adalah pelajaran yang paling mereka sukai, karena menurut mereka kimia digunakan dalam kehidupan sehari-hari, sehingga pada saat kegiatan belajar mengajar, siswa terlihat serius dan berkonsentrasi dengan baik. Sebagian juga siswa tidak senang belajar kimia dan menganggap pelajaran kimia adalah pelajaran yang sulit, hal ini dikarenakan cara guru dalam membawakan materi pelajaran yang sulit dimengerti oleh siswa dan kurangnya guru memberikan latihan contoh soal yang dapat mempermudah siswa dalam memahami materi pelajaran serta terlalu banyak rumus yang harus diketahui. Dari refleksi terhadap metode pembelajaran kooperatif tipe Jigsaw, mereka menyarankan agar dalam menjelaskan materi pelajaran selalu diulangi dan meminta agar metode pembelajaran kooperatif tipe Jigsaw lebih sering digunakan dalam proses belajar mengajar kimia, sebab sangat mendukung sebagai prasarana belajarnya. 
2) Manfaat metode pendekatan pembelajaran kooperatif tipe Jigsaw pada proses belajar mengajar

Pada umumnya siswa senang dengan pembelajaran kooperatif tipe Jigsaw pada pembelajaran karena dapat membuat mereka rajin belajar. Dengan banyaknya tugas yang diberikan oleh guru dapat membuat mereka termotivasi untuk terus belajar juga menganggap bahwa metode pembelajaran kooperatif tipe Jigsaw sangat baik, mereka dengan metode pembelajaran kooperatif tipe Jigsaw, maka:

a) Siswa lebih mudah mengerti, yang berarti mereka merasakan pengalaman belajar dengan pembelajaran kooperatif tipe Jigsaw.

b) Siswa lebih mudah mengerti karena mengerjakan soal-soal latihan secara bersama dengan anggota kelompok masing-masing.

c) Siswa mudah mengingat pelajarannya pada saat pemberian ulangan juga bisa menjawab dengan mudah pertanyaan-pertanyaan yang diajukan sesuai dengan materi yang diajukan.

d) Siswa meningkat prestasi belajarnya.

Pendapat siswa di atas diambil dan wawancara tertulis dengan 35 orang siswa sebagai responden peneliti. Gambaran wawancara siswa diambil secara acak sebanyak 1 lembar tanpa dibubuhi dengan identitas. Jawaban wawancara siswa tidak dibubuhi dengan identitas dimaksudkan agar peneliti tidak terganggu.

\section{Kesimpulan}

Berdasarkan hasil yang diperoleh dalam penelitian ini maka dapat ditarik kesimpulan bahwa: (1) Terjadi peningkatan hasil belajar kimia siswa dalam kategori tinggi siklus I dan kategori tinggi pada siklus II. (2) Terjadi peningkatan persentase pencapaian hasil belajar siswa, pada siklus I sebesar 42,9 \% yaitu 15 dari 35 siswa dinyatakan tuntas belajar, sehingga telah tercapai hasil belajar secara klasikal. (3) Terjadi peningkatan persentase pencapaian hasil belajar siswa, pada siklus II sebesar 71,4\% yaitu 25 dari 35 siswa dinyatakan tuntas belajar sehingga telah tercapai hasil belajar secara klasikal.

\section{Saran}

Adapun saran yang disampaikan berdasarkan hasil penelitian ini adalah metode pembelajaran kooperatif tipe Jigsaw dapat digunakan oleh guru-guru lain pada saat proses belajar mengajar berlangsung di dalam kelas sehingga siswa lebih mudah mengerti dan menganggap bahwa mata pelajaran kimia bukan merupakan mata pelajaran yang menakutkan. Guru perlu menguasai beberapa metode mengajar sehingga pada pelaksanaan proses belajar mengajar di kelas dapat dilakukan metode bervariasi sesuai dengan materi yang diberikan agar siswa tidak bosan belajar dan siswa mudah memahami materi pelajaran dan juga sebagian motivasi untuk memperhatikan apa yang diajarkan guru.

\section{DAFTAR PUSTAKA}

Asni, H. (2017). Upaya Meningkatkan Aktivitas dan Hasil Belajar Peserta Didik Melalui Penerapan Pendekatan Cooperative Learning Tipe Jigsaw di Kelas III-A SD Negeri 2 Cakrangeara. Jurnal Kependidikan: Jurnal Hasil Penelitian dan Kajian Kepustakaan di Bidang Pendidikan, Pengajaran dan Pembelajaran, 3(2). doi:https://doi.org/10.33394/jk.v3i2.567

Aspari, A. (2020). Upaya Meningkatkan Hasil Belajar Siswa Melalui Penerapan Metode Pembelajaran Jigsaw Berbantuan Modul pada Siswa SMA Negeri 2 Labuapi. Jurnal Teknologi Pendidikan : Jurnal Penelitian dan Pengembangan Pembelajaran, 5(2), 
126-131.

Retrieved

from https://ejournal.undikma.ac.id/index.php/jtp/article/view/3058

Faiq. M. (2009). Model Pembelajaran Kooperatif. Jakarta : Rineka Cipta

Fajuri, F. (2019). Penerapan Pendekatan Cooperative Learning Tipe Jigsaw dalam Upaya Meningkatkan Aktivitas dan Hasil Belajar Peserta Didik Kelas I SD Negeri 27 Ampenan. Jurnal Paedagogy, 6(1), 20-26. doi:https://doi.org/10.33394/jp.v6i1.2526

Halling, Abd. (2006). Belajar dan Pembelajaran. Makassar: Badan penerbit UNM Hasibuan dan Moedjiono. (2008). Proses Belajar Mengajar. Bandung: Remaja Rosdakarya Heryekti Pujingsih, R. (2021). Meningkatkan Motivasi dan Hasil Belajar Matematika dengan Metode Kooperatif Tipe Jigsaw di SMA Negeri 1 Gerung. Jurnal Paedagogy, 8(1), 50-56. doi:https://doi.org/10.33394/jp.v8i1.3196

Ibrahim. (2000). Peningkatan Profesionalisme Guru dalam Mengajar.Bandung.Penebar Swadaya

Karlina, Ina. (2004). Pembelajaran Kooperatif Sebagai Salah satu Strategi Membangun Pengetahuan siswa. Diakses tanggal 4 November 2009

Nashirotun, B. (2020). Peningkatan Aktivitas dan Hasil Belajar Siswa dengan Metode Jigsaw dan Media Tubuh Manusia pada Pembelajaran IPA di MTs. Negeri 4 Klaten Jawa Tengah. Jurnal Paedagogy, 7(4), 402-407. doi:https://doi.org/10.33394/jp.v7i4.2945

Nur, M, dkk. (2000). Model Pembelajaran Kooperatf . Surabaya : University Press

Pratini, P. (2015). Upaya Meningkatkan Aktivitas dan Hasil Belajar PKn Siswa Kelas VIII-B SMPN 18 Mataram Melalui Penerapan Pendekatan Cooperative Learning Tipe Jigsaw. Jurnal Kependidikan: Jurnal Hasil Penelitian dan Kajian Kepustakaan di Bidang Pendidikan, Pengajaran dan Pembelajaran, 1(2). doi:https://doi.org/10.33394/jk.v1i2.417

Sardiman A.Haryono. (2008). Media Pendidikan. Jakarta: PT.Raja Grafindo Persada Slameto. (2003). Belajar dan Faktor-faktor Yang Mempengaruhinya. Jakarta: Rineka Cipta Suherman, E, I-I, dkk. (2003). Strategi Pembelajaran Kontemporer. Bandung. JICA. Wasis dan Sugeng. (2008). Ilmu Pengetahuan Alam SMP/MTs Kelas XI IPA 1. Jakarta : Departemen Pendidikan Nasional 